\title{
"BUT WHICH ONE IS RIGHT?": USING COMPETING INTERPRETATIONS OF EASTER ISLAND TO TEACH HISTORIOGRAPHICAL THINKING
}

Benjamin J.J. Leff

University Laboratory High School, Urbana, Illinois

There is a moment in a documentary about Easter Island that always makes me smile, but it flummoxes many of my students. The documentary, called Easter Island in Context: From Paradise to Calamity, features numerous interviews with archaeologists who have researched the history of society on Rapa Nui (the name used for Easter Island by its indigenous inhabitants). ${ }^{1}$ The relevant moment in the film concerns a historical puzzle regarding the giant stone heads for which the historically isolated Pacific island is so famous: How did the inhabitants of Rapa Nui transport these enormous multi-ton statues to platforms that are often miles away from the quarry from which the stone was extracted? Archaeologist Paul Bahn hypothesizes that the Rapanui "may have moved some, or certainly a few of the statues, by water." At this point in the film, the students dutifully start writing down this explanation in their notes, but halfway through their sentence they are interrupted by a different interview with an archaeologist named Georgia Lee, who contends, "I don't think they floated anything around the island. Give me a break." The film then continues to cut back and forth between the interviews of two scholars:

Bahn: It takes all the weight away from the object you're trying to move. Most of the platforms are around the coast.

\footnotetext{
1 In this article, I will generally follow scholarly convention by referring to Easter Island as Rapa Nui, and to the indigenous inhabitants of the island as the "Rapanui."

(C) 2019 Leff. Free to copy and share for education and scholarship under a Creative Commons Attribution NonCommercial-NoDerivatives 4.0 License.
} 
Lee: The coastline is really jagged, and rugged, and rocks, and lava.

Bahn: They had a big canoe ramp well-built down to the ocean, have a large raft waiting there, and then simply float it around to the canoe ramp nearest your platform.

Lee: I think it would be far more trouble, particularly if you don't have a lot of wood. What are you going to float them on? Come on. Nah, I don't think so. ${ }^{2}$

By this point, some students are laughing, but other students are clearly exasperated. Some even look at me plaintively and hopefully, a seeming nonverbal request for official adjudication of the dispute. Both archaeologists are experts, so which one is right? When I pause the video a few minutes later, I say something like: "I love that moment when the two archaeologists are arguing. Why does that moment make me so happy as a history teacher?" Sure enough, a few intrepid students are able to successfully read my mind, replying (in so many words) that this demonstrates the challenges of uncovering "what really happened" in the past, and that historical inquiry is often defined by debate between competing interpretations of the past rather than uncontroversial consensus.

\section{Why Teach Historiographical Debate?}

This anecdote illuminates a subject that is commonly discussed in history education circles. Historian Lendol Calder has argued for the importance of developing a "signature pedagogy" in history courses, in which students learn not only historical content but also how to think like a historian. In Calder's words, history teachers should try to inculcate the "values, knowledge and manner of thinking" that define the historical discipline rather than merely attempt to cram historical information into

\footnotetext{
2 Easter Island in Context: From Paradise to Calamity, directed by Peter A. Steen. (2002, West Hollywood, CA: Adler Media). Accessed June 4, 2018. http://fod. infobase.com/p_ViewPlaylist.aspx?AssignmentID=ZMNTZJ
} 
their students' heads. ${ }^{3}$ If our goal as history instructors is indeed to help students learn how to "do" history as practitioners do it, then surely we must expose them to the study of historiography. Any history graduate student would attest that a substantial part of their training involves learning about debates between historians regarding proper interpretation of certain historical topics, as well as studying continuity and change regarding which interpretations and modes of inquiry have prevailed over time.

However, it is probably fair to speculate that many high school and college history classrooms give scant attention to historiography. The classic history textbook is written in what history education scholar Sam Wineburg calls the "omniscient third person," thus eliminating "metadiscourse...the places in the text where the author intrudes to indicate positionality and stance." ${ }^{4}$ In this way, the contested nature of history is hidden from the student. Similarly, the teacher in a traditional history classroom is assumed to have similar "omniscient" qualities, serving as the student's ultimate authority by offering the definitive interpretation of history. The paradigm of the test, premised on the idea that students will be rewarded for providing the "right answers," reinforces the idea that students are supposed to be learning a particular "correct" interpretation of the past. Thus, the entire mode of traditional historical instruction serves to obscure historical debate and interpretative contestation-highly ironic given how central these activities are to the professional lives of academic historians. Thus, if we aim to develop a signature pedagogy for the history classroom-if we truly wish to teach students how to think like historians rather than merely convey "what happened" in the past-we must not just teach historical thinking, but what scholars Thomas Fallace and Johann Neem

\footnotetext{
3 Lendol Calder, "Uncoverage: Towards a Signature Pedagogy for the History Survey," Journal of American History 92, no. 4 (2006): 1361.

4 Sam Wineburg, Historical Thinking and Other Unnatural Acts: Charting the Future of Teaching the Past (Philadelphia: Temple University Press, 2001), 12-13.
} 
have called "historiographical thinking."5

At the most basic level, "historiographical thinking" is built on the premise that "history" is not a self-evident rendering of the past; instead, there is an array of historical interpretations that exist at any given moment. At one level, professional historians think historiographically by relating any new information to their knowledge of what other scholars have already written on a given topic. Of course, students in a survey course can never be expected to be familiar with the existing literature on the subjects they encounter in class, but they can start to think historiographically in two ways. First, they can learn to relate a historical interpretation to the social and historical context in which it was written. For example, on one of my assignments, I provide an account of Reconstruction written in 1901 by historian (and future President) Woodrow Wilson, and I ask students to explain how his interpretation is typical of the racial attitudes that prevailed during the Jim Crow era. ${ }^{6}$ Second, students can learn that at any given moment, there are multiple interpretations of

5 Thomas Fallace \& Johann Neem, "Historiographical Thinking: Towards a New Approach to Preparing History Teachers," Theory and Research in Social Education 33, no. 3 (Summer 2005): 329-346.

6 See Woodrow Wilson, "The Reconstruction of the Southern States," Atlantic Monthly (January 1901) at https://www.theatlantic.com/magazine/archive/1901/01/ the-reconstruction-of-the-southern-states/520035/ Indeed, Reconstruction provides an excellent opportunity for teaching historiographically. Early twentieth-century American historians portrayed Reconstruction as a tragic mistake, in which the South was misgoverned because African-Americans were supposedly "incapable of responsibly exercising the political power that had been thrust upon them." This interpretation was turned entirely on its head in the wake of the Civil Rights Movement. Post-1960s historians portrayed black suffrage as a noble step towards racial equality; the "misgovernment" of the South came when so-called Redeemers installed an exploitative regime of racial segregation and disenfranchisement. Thus, a student who is thinking historiographically would recognize that each historical interpretation aligns with the racial ideology that prevailed in that time period. For the quote above and a more robust (yet concise) summary of these historiographical trends, see Eric Foner, "Slavery, Civil War, and Reconstruction," in The New American History, ed. Eric Foner (Philadelphia: Temple University Press, 1997), 96-103. 
the past-sometimes complementary, but sometimes competing. Teachers can help students hone historiographical thinking skills by confronting them with pairs of secondary sources discussing the same topic and having them evaluate each argument and determine which explanation is more compelling. Thus, while students in an introductory survey could never be expected to master the historiography on a given subject, they can learn to analyze history as a set of (potentially competing) interpretations of the past.

However, certain intelligent and reasonable people might believe that teaching discipline-specific historical thinking skills is misguided. To channel this hypothetical perspective: Very few high school students will end up being professional historians, so why teach them how to think like historians? Instead, the teacher should stay focused on teaching what happened in the past rather than waste energy teaching modes of inquiry that are only relevant to professional practitioners. To the extent that we should teach students "thinking" skills, they should be generic analytical skills that could be applied in any context. I do not hold this view, and I do not imagine that anyone reading a history education journal does either. Nevertheless, even if one concedes the point and agrees that history teachers should be teaching generic skills, there is still a compelling argument that students benefit from an approach that views history as an arena for competing interpretations. This is because even though few high school history students will become professional historians, nearly all will become citizens (or at least, participants in a civic culture). And in that respect, it is invaluable that students gain experience encountering competing interpretations of "truth," identifying key points of agreement and disagreement between those interpretations, and assessing which interpretations are most compelling.

Honing these skills is especially crucial given the nature of the "information ecosystem" that today's students inhabit.7

7 Much ink has been spilled on this subject, but this term is drawn from a thoughtful 
When presented with a question about history or politics or society, we have all learned the quick way to arrive at an answer: Google it. Indeed, we should be deeply grateful for the amount of information that is readily available at our fingertips. However, for most important topics, discovering "what happened" is not so simple-and deeper questions like "how?" and "why?" are even harder to definitively answer. This is because the proliferation of accessible information doesn't necessarily lead to clarityit can in fact obscure it by multiplying the number of available interpretations. Furthermore, the information ecosystem is rife with pitfalls, as misinformation and bias compromise the reliability of the easily accessible data on the internet. Additionally, as consumers, we bring our own preconceptions and a proclivity towards confirmation bias, defined by Alan Miller as the tendency of people "to seek confirmation of their existing beliefs, rather than information that might contradict or complicate them." Given that students inhabit this exciting but treacherous informational terrain, teaching historical thinking is a valuable means to enhance what is becoming an ever more important information literacy skill: assessing the reliability of information by deconstructing arguments and deducing the potential biases of an author. ${ }^{9}$ This skill, such an essential component of historical thinking, is also important when seeking to understand contemporary social and political debates, whether one is weighing competing arguments for differing immigration policies or seeking to understand different explanations of the roots of the gender wage gap. It may be impossible in many of these situations to definitively decide

2016 article: Alan C. Miller, "Confronting Confirmation Bias: Giving Truth a Chance in the Information Age," Social Education 80, no. 5 (October 2016): 276.

8 Ibid., 277.

9 To be sure, I do not mean to imply that only with the rise of the internet did students need to learn to assess the reliability of a source or an author's bias. However, it is also fair to say that the internet has produced an increasingly fragmented mediascape and the collapse of various barriers to publication. In such an environment, learning to critically approach and assess the quality of information has become increasingly important. 
which interpretation is right, but students will surely benefit from getting practice judging which arguments are more compelling and exploring how competing interpretations might be reconciled.

\section{An Opportunity for Teaching Historiographical Debate: What Happened to Rapa Nui?}

To help my students develop these skills, I teach a multi-day lesson on Rapa Nui, the island I discussed at the outset of this article. The "mystery" of Rapa Nui is often portrayed thusly: By the end of the nineteenth century, the society of Rapa Nui had collapsed. Once home to thousands of inhabitants, the island's population dwindled to hundreds if not dozens, the forests had been destroyed, and numerous plant and animal species had gone extinct. What happened? Without decipherable written records that precede European arrival, scholars have to rely primarily on the interpretation of physical evidence to answer that question. ${ }^{10}$ As part of my lesson, students read and compare two scholars' competing interpretations of that evidence to explain the fate of Rapa Nui. The traditional view is articulated by geographer and popular scholar Jared Diamond, who argues that the Rapanui experienced swift population growth and eventually exhausted their island's resources, triggering societal collapse. The revisionist view is articulated by archaeologist Terry Hunt, who argues that the archaeological record isn't consistent with human-induced societal collapse. ${ }^{11}$

In addition to having students engage with a very interesting historical question - what really happened to the Rapanui? - this lesson helps students hone their historical and historiographical thinking skills. First, it requires students to unpack arguments.

\footnotetext{
10 The Rapa Nui actually did have a script called Rongorongo, but it has yet to be deciphered.

11 Jared Diamond, "Easter's End," Discover 16, no. 8 (August 1995): 63-69 and Terry Hunt, "Rethinking the Fall of Easter Island," American Scientist 94 (January 2006): 412-419. A more robust description of the two arguments will be provided in the next section of the article.
} 
Both Diamond and Hunt deploy evidence that leads to distinct interpretative claims, and they ultimately arrive at different conclusions about the history of Rapa Nui. This lesson gives students good practice identifying these components of historical arguments. Second, students get practice evaluating arguments. Students will ultimately weigh the interpretations of the two scholars, and in the process, determine what features of an argument make it compelling or suspect.

Finally, this activity underscores two meta-points about history referenced earlier in the essay. First, there is rarely one unquestioned view of a historical event or process. Scholars are nearly always debating - which is both frustrating and exciting. Second, scholars' arguments can be driven by external agendas. Students will discover that Diamond is using the Rapa Nui "ecocide" as a cautionary tale about human-induced environmental destruction; such an agenda may lead students to distrust his analysis. Similarly, Hunt could have his own motivations for "taking down" Jared Diamond that are separate from the noble pursuit of the truth. Thus, this lesson provides students an opportunity to hone skills that are vital to historiographical thinking as well as more broadly applicable critical thinking skills in today's digital information landscape.

In the coming paragraphs, I will explain the procedure for this multi-day lesson in some detail, but I will first situate it within my broader curriculum. This lesson was taught as part of a World History course taught to freshmen at University Laboratory High School, a selective-admission public laboratory school in Urbana, Illinois. However, the subject matter is sufficiently complex that it could easily be taught to older high school and college students. ${ }^{12}$ The lesson was part of a one-week "mini-unit" on

12 This was not an AP World History course, as our school does not offer AP courses (instead, all classes are considered to be "honors" classes since our school explicitly serves "academically talented" students). The course was global in geographic scope, but technically limited chronologically to the period between $2000 \mathrm{BCE}$ and $1500 \mathrm{CE}$, as it is followed by a Modern History course that students take as sophomores. Thus, 
Austronesian society, and as such, was preceded by a background lesson about the Austronesian people who first settled hundreds of Pacific islands centuries before Europeans arrived. ${ }^{13}$ Then I focus more specifically on the Austronesian inhabitants of Rapa Nui, discussing some features of their society, including the moai statues that have achieved worldwide fame. The giant stone statues are more than an intriguing curiosity, but instead offer compelling evidence about the structure of Rapa Nui society. The historian can infer much from their giant size (a typical statue weighs over ten tons, and some weigh much more) and the significant distance between the quarry from which the stone was extracted and their mounting site. The substantial effort required to construct and transport these statues requires a level of collective endeavor that implies some degree of social hierarchy and complex organization. The placement of collections of moai statues on different ahus (platforms) throughout the island indicates the presence of sociopolitical divisions-different clans (called mata) each with their own ceremonial center. According to Rapanui oral tradition, the statues were believed to hold the mana, or spiritual "energy," of particular ancestors who continued to watch over their mata after death. In sum, the cult of the moai tells a story about Rapa Nui social structure and culture.

One other detail about the moai points to the real focus of my

as you will see, I was slightly "cheating" in this lesson by discussing developments that occurred after 1500, outside the chronological barriers of my class.

13 To provide slightly more detail: I start the unit by laying out the "mystery" of the Austronesians. Simply put, when and how did these people manage to settle these islands across thousands of miles of ocean water? I then briefly discuss evidence from botany and oral tradition, but spend the most time doing an activity based on linguistic evidence. I give students information about the common "Austronesian" language family and have them map the Pacific migration based on that evidence. After this activity, I explain the prevailing theory about how the Austronesian people migrated, the culture of the Austronesian peoples, and what kind of societies they set up in the Pacific islands. At this point, students are ready to understand the development of society on Rapa Nui as part of the broader context of Austronesian migration. If you are interested in how I teach any of this material, I am happy to correspond via email at leff@illinois.edu. 
lesson: Many of them were destroyed by the Rapanui themselves. By the time Europeans arrived, many had been toppled, and some were even deliberately pushed down onto stones such that the moai were decapitated. In some cases, the eyes-which were believed to hold the statue's mana-were deliberately crushed. This strongly indicates some kind of warfare on the island, likely between the different mata. Around the same time as the moai were being desecrated, there was a significant population drop on the island. This speaks to the tantalizing question at the heart of my lesson: What happened on Rapa Nui that led a flourishing society to descend into chaos? ${ }^{14}$

14 Most of the information in the preceding paragraphs can be found in Steen, Easter Island in Context. This valuable documentary features interpretations and analysis from a number of scholars who study society on Rapa Nui. Additional information is drawn from Diamond, "Easter's End," and Hunt, "Rethinking the Fall of Easter Island." 


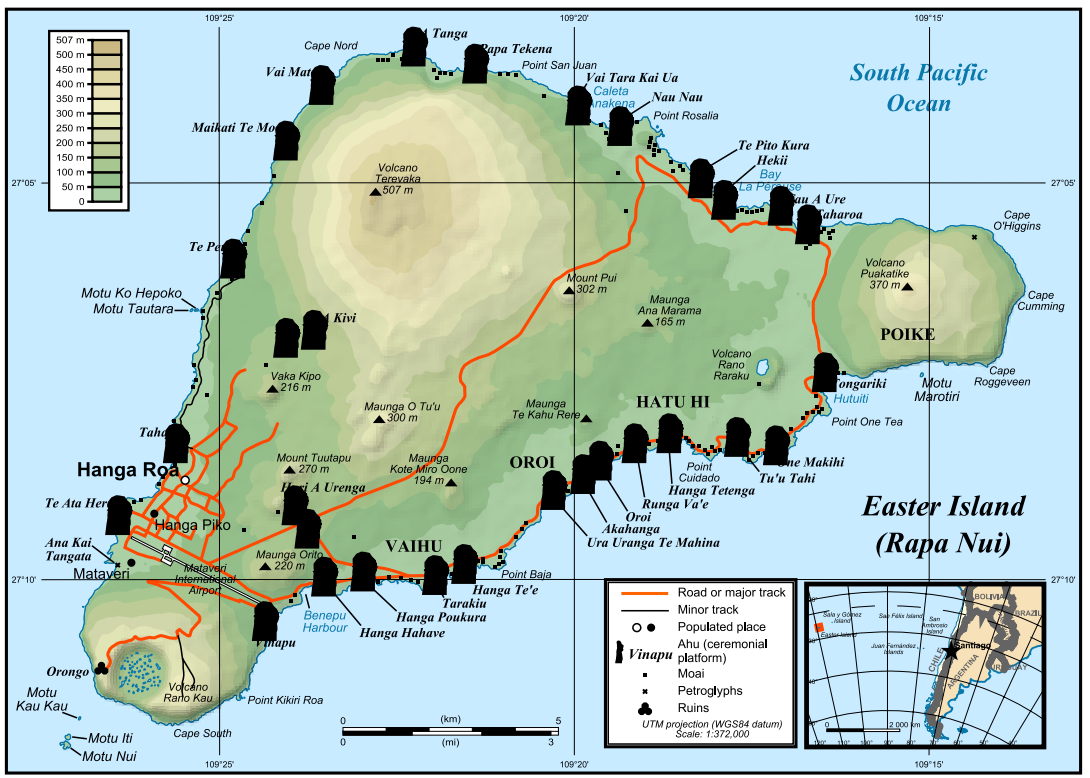

Figure 1: This map shows that all of the stone for the massive moai had to be transported significant distances from the quarry at Rano Raraku (towards the east of the island) to the various ahu (platform) sites. Scholars have concluded that completing such a formidable project would have required complex social organization. Additionally, the fact that ahu (platforms) are spread throughout the island supports the interpretation that Rapa Nui was socio-politically divided among numerous mata (clans). ${ }^{15}$

15 Eric Gaba, Easter_Island_map-en.svg, Digital Image, Wikimedia Commons, December 10, 2011, https://commons.wikimedia.org/wiki/File:Easter_Island map-en. svg. 


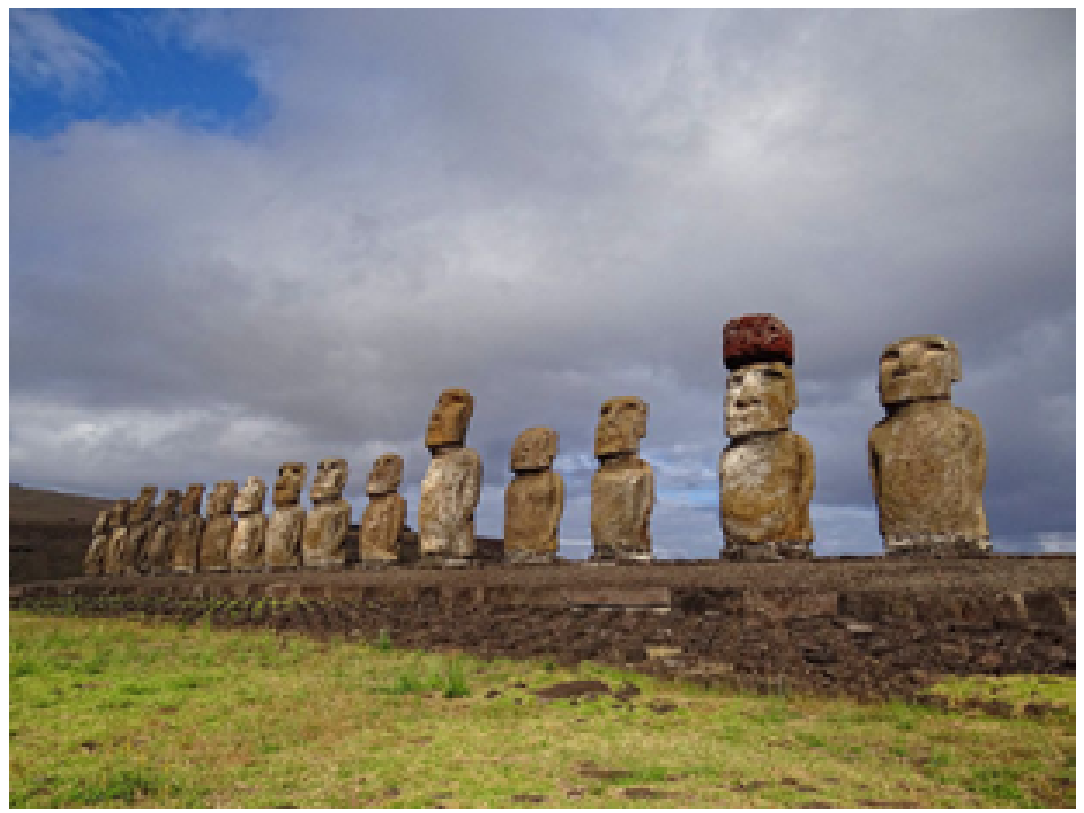

Figure 2: This image shows a collection of moai at Ahu Tongariki. These statues are massive: They range between 18 and 28 feet tall, and one weighs over eighty tons. ${ }^{16}$

\section{Pre-Work: Competing Arguments Regarding the "Fall" of Easter Island}

In preparation for this lesson, I provide students with truncated versions of two articles to read for homework. The first is "Easter's End" by Jared Diamond, published in Discover Magazine in 1995 (though he also reworked and expanded these ideas in a chapter of his 2005 book, Collapse). Diamond argues that Rapa Nui presents a tragic example of human-induced environmental catastrophe. The first humans to arrive on the island encountered a "miniature paradise" with fertile soil and abundant resources. For a time,

16 Bjørn Christian Tørrissen, Ahu-Tongariki-from-south-west-2013.jpg, Digital Image, Wikimedia Commons, May 8, 2014, https://commons.wikimedia.org/wiki/ File:Ahu-Tongariki-from-south-west-2013.jpg. 
society flourished. A population of at least 7,000 (and perhaps as high as 20,000) developed "complex political organization" to extract, transport, and redistribute the goods scattered across the island. But the trappings of this successful society disappear from the archaeological record during the middle of the second millennium CE. The forests were decimated, myriad animal species were driven to extinction, and the Rapa Nui even stopped building their famous moai statues. Seeking to explain this calamity, Diamond argues that the Rapa Nui rapaciously and myopically felled the forest to extract wood for cooking, housing, canoes, and rolling logs to transport the massive moai. The destruction of the island's natural environment resulted in food scarcity that ultimately led to catastrophic population declines (down to a few thousand by the time Europeans first arrived), increased warfare, and social breakdown (there is even evidence of cannibalism). Diamond concludes by writing that "the meaning of Easter Island for us should be chillingly obvious. Easter Island is Earth writ small." In Diamond's view, as humans decimate our planet's resources, we risk inducing our own tragic collapse unless we "choose to learn from the fates of societies like Easter's." 17

The second article is "Rethinking the Fall of Easter Island" by Terry Hunt, published in American Scientist in 2006. Hunt relates at the outset of the article that he came to Rapa Nui intending to confirm the traditional narrative expounded by Diamond and others, but his research unearthed evidence that contradicted the prevailing theory. First, Hunt's studies of a beach on Rapa Nui indicated that the island was not settled until as late as $1200 \mathrm{CE}$ (instead of previous estimates of habitation by $800 \mathrm{CE}$ or perhaps even earlier). This difference is significant because it renders infeasible Diamond's argument for anthropogenic deforestation, which started far too quickly after $1200 \mathrm{CE}$ to be blamed directly on humans. This brings Hunt to his second point: Rats, not humans, were responsible for deforestation. Ample archaeological

17 Diamond, "Easter's End," 63-69. 
evidences indicates that rats arrived and flourished on the island, dining on the seeds of the palm trees, preventing the species from reproducing and quickly destroying the forest. As such, humans were only indirectly responsible for the island's deforestation, as the true culprits were the rats they brought with them. Third, Hunt argues that Diamond's peak population estimates are far too high. Instead, he argues that the human population never rose above 3,000 . If this is true, there was no dramatic pre-European social collapse as described by Diamond. Instead, there was a society that steadily eked out an existence for centuries until the arrival of Europeans, who brought devastating diseases and enslaved the inhabitants of the island. In Hunt's words, "it was genocide, not ecocide that caused the demise of the Rapanui." 18

Thus, students encounter two decidedly different arguments about the history of society on Rapa Nui. In addition to reading the articles for homework, I have students craft a written response in which they complete three tasks. First, they are asked to paraphrase both authors' arguments. I rarely ask students to merely paraphrase an article, but in this case, it is important for students to really focus in on the structure of each author's argument. I am assessing whether students can identify the author's central argument, the major claims supporting that argument, and some of the evidence that supports those claims-in other words, whether they can map what I call the "anatomy" of each argument. Second, I ask students: What do Diamond and Hunt fundamentally disagree about? Hopefully, students do not merely identify that the two authors draw different conclusions about what happened to the Rapa Nui. Instead, they should articulate that the authors' different macro-conclusions rest on disagreements about the cause of deforestation, peak population size, and estimated human arrival date. Third, I have students write down two researchable questions that would help them decide which author is correct. Ideally, this forces students to identify the pivotal disagreements between the

18 Hunt, "Rethinking," 412-419. 
two authors and consider the kinds of historical evidence that could help resolve their disputes. ${ }^{19}$

\section{Class Discussion: Deconstructing and Assessing Arguments}

Given that not every student fully grasps both articles at first, it is important to start class with a discussion in which the class collectively maps out each argument. I start by elucidating Diamond's argument, careful to make sure that students are articulating the links between evidence and conclusions. Then I lead a discussion of Hunt's argument, asking students to articulate Hunt's challenges to Diamond. I push students to not only discuss the "discrepancies" that Hunt discovers, but also articulate why those discrepancies affect Diamond's argument. Below is a "discussion map" for each article.

\section{Discussion Questions for Diamond article}

- According to Diamond, what are some aspects of Rapa Nui society that had disappeared by the 1800 s?

- According to Diamond, why did this social collapse ensue?

- Why didn't the Rapa Nui change their ways to avoid this environmental destruction?

- To Diamond, Easter Island is a cautionary tale. How are Easter Island and Earth similar? What's the moral of this story for our society?

\section{Discussion Questions for Hunt article}

- When does Hunt believe humans first arrived on Rapa Nui? Why does this challenge Diamond's argument?

- What does Hunt believe really caused the deforestation on the island? What evidence supports that claim?

- According to Hunt, what was the peak population on Rapa Nui? Why does that challenge Diamond's argument for social collapse?

- What does Hunt mean when he says that "it was genocide not ecocide?"

19 Many of my students "nailed" this assignment, successfully articulating the structure of each argument, the crucial disagreements between the authors, and thoughtful research questions (for example, one student got to the crux of the issue by asking "What were the peak populations of humans and rats on the island, and at what time did they occur?"). Others struggled to offer more than superficial renderings of each argument and posed research questions that failed to get to the meat of the debate. For example, one student asked, "What is the Europeans' viewpoint on how they treated the Rapanui?" This is an interesting historical question, but knowing the answer would not help us settle the dispute between Diamond and Hunt. 
After mapping out the two arguments, we get to the fun part; I ask students with whom they agree. In my experience, this part of the discussion runs itself quite well, as the students argue with each other quite enthusiastically. As a teacher, one is tempted to just sit back and watch, and there is some value in letting students drive the discussion. However, I also find that it is important to intervene at times to move the discussion in the best direction. For example, I often step in to force the students to explain their reasoning for supporting a particular argument, or to explain why they think an author's reasoning is flawed or biased-they need to not just assert but defend their views by articulating logical support. Additionally, depending on the class, I have sometimes found it necessary to play devil's advocate. Students generally end up siding with Hunt, in part because they read Hunt's critique of Diamond but not Diamond's counter-defense. ${ }^{20}$ I push students, for example, to think about the potential weaknesses in Hunt's argument; for example, he argues for a later date of human arrival based on findings from one beach, but what about evidence of human habitation on other beaches?

\section{Meta-Discussion: Uncovering Potential Agendas}

To close the discussion, I ask students: "What's the moral of this story?" That is, what broader lessons about "doing history" are illuminated that transcend the specific question of "What really happened on Rapa Nui?" I typically allow students to discuss this in small groups before opening a large-group discussion on the subject, and students generally come up with valuable insights. For example, a student will always point out that the "truth" about the past is not always clear, and historians often debate which version of history is correct. Along these lines, students often

20 Diamond's response is available online. See Jared Diamond, "The Myths of Easter Island-Jared Diamond Responds," Mark Lynas, last modified September 22, 2011, http://www.marklynas.org/2011/09/the-myths-of-easter-island-jared-diamondresponds/ 
make valuable points about the importance of remaining openminded rather than only looking for evidence that supports a pre-ordained conclusion. It is also common for students to say that history can teach us lessons about the present-that is, they channel Diamond's argument that the destruction of society on Rapa Nui has something to teach us about what we are doing to our own environment.

These are all valuable points, but I ultimately try to build towards a discussion of an author's agenda-the underlying motives or goals that inform an author's work. Without fail, a student will point out that for Diamond, Easter Island functions as a fable about self-induced environmental destruction. As such, we have some reason to be skeptical of Diamond's claims because he has an environmentalist agenda-made clear in statements like "If we continue to follow our present course, we shall have exhausted the world's" resources and that "my main hope for my sons' generation is that we may now choose to learn from the fates of societies like Easter's." Students speculate that this concern might have driven Diamond to see human-caused environmental destruction as the culprit on Easter Island because he is worrying about the damage humans are currently doing to our environment. Indeed, this potential for distortion is nearly always present when people make historical analogies, which are frequently deployed to serve some ideological end. If it has not already emerged in class discussion, I introduce students to the concept of "confirmation bias," that once someone has an interpretation (particularly one in which they are personally invested), they will tend to look for evidence that confirms that interpretation and discount evidence that challenges it.

While students are quick to identify Diamond's potential agenda, they are less likely to see such ulterior motives at work in Hunt's article. Indeed, Hunt explicitly states at the outset of his article that he came to Easter Island expecting to confirm the traditional interpretation of anthropogenic catastrophe, which 
lends him credibility in the eyes of many students. However, I try to give students hints that point to a potential agenda driving Hunt's interpretation. I ask students whether it could be professionally advantageous for a scholar to challenge an existing theory. I also point out that unlike Hunt, Diamond is the rare example of an academic who has become a bestselling author, with enormously successful books like the Pulitzer Prize-winning Guns, Germs, and Steel. Armed with those hints, a student usually infers that Hunt might have a personal or professional incentive to challenge the canonical interpretation of a well-known scholar. In academia, there is a premium on work that "advances the field," and as such, an article that successfully challenges the prevailing perspective has the potential to make more of a "splash" than another article that affirms the existing interpretation. As such, Hunt could be eager to find evidence that challenges the traditional views regarding Rapa Nui, becoming susceptible to another form of confirmation bias.

I close this discussion by making a clear disclaimer to my students, and I figure I owe the same disclaimer to the readers of this article. I do not know whether Diamond or Hunt deserves to be criticized for allowing an agenda to distort their scholarshipin particular, the hypotheses about Hunt's agenda are quite speculative. Both scholars are far more formidable than I, and far more knowledgeable about Rapa Nui. Indeed, as consumers of scholarship, we nearly always will be reading work by scholars who know more about the subject than we do. But that does not require us to suspend a critical perspective. Whether we are reading scholarly work, a newspaper article, or a Facebook post, we must cultivate a healthy skepticism and always be on the lookout for an agenda that could compromise an interpretation. We must critically consider various aspects of any argument: the selection of evidence, the logical strength of interpretations of that evidence, and the coherence of an overarching argumentall while being mindful of how a preexisting agenda might be at work. 


\section{Extension Activity: Refining Evaluation of Arguments with Supplemental Research}

I finish the mini-unit with an activity that allows students to conduct further research to help them determine which scholar's interpretation is more persuasive. I personally believe that it is not really possible for students to meaningfully "pick a side" based merely on the articles by Hunt and Diamond. Both authors offer promising but potentially flawed interpretations, and in both cases, we would want to learn more before determining whose interpretation of Rapa Nui is correct. To this end, I split the students into groups of around four students for a research activity in which their job is to find more information that helps them assess which argument they find more compelling. ${ }^{21}$ Each group's first task is to determine a set of researchable questions that will help them achieve this goal. Crucially, these should not just be any questions about Easter Island. They should be questions to speak to the fundamental disagreements between Hunt and Diamond. ${ }^{22}$ Students are then tasked with identifying articles that can help answer these questions, an endeavor that requires them to hone their skills as savvy consumers of information on the internet. I have some students use library databases and have some students use Google to find articles. ${ }^{23}$ As each group member finds reputable

21 Most recently, I used a 105-minute "finals period" to complete this activity, but some of the work could be done for homework in order to save class time.

22 Some examples of valuable research questions could be: When exactly did humans arrive on the island? What was the peak population on Rapa Nui? What was the relative importance of humans vs. rats in effecting the deforestation of the island? What evidence is there of increased violent conflict on the island?

23 Our high school is part of the University of Illinois, and therefore has an immense array of databases that would not be available to the average high school student. However, Google also allows them to find some gems. Some students were overjoyed to find Diamond responding to criticism from Hunt and another scholar named Carl Lipo, as well as Hunt and Lipo responding to Diamond's response! See Jared Diamond, "The Myths of Easter Island-Jared Diamond Responds," and Carl Lipo and Terry Hunt, "The Myths of Easter Island_-Jared Diamond Responds," Mark Lynas, last modified October 10, 2011, http://www.marklynas.org/2011/10/the-easterisland-ecocide-never-happened-response-to-jared-diamond/ 
sources, they write down the citation information from the article, why they consider it to be a reputable source, and a summary of information in the reading that confirms, rebuts, or qualifies Hunt and Diamond's arguments.

A few valuable "meta-lessons" emerge from this process. First, students must pay close attention to the date of publication of their sources. More recent research deserves extra consideration, especially because scholars have developed more sophisticated scientific techniques for interpreting archaeological artifacts in recent years. In particular, students should look for articles published after 2006, when Hunt's work reframed the Rapa Nui debate. Second, students should pay close attention to where the information is coming from in a given article. For example, some students found popular science articles that seemed to corroborate Hunt's argument. But upon closer examination, it became clear that these articles were merely using Hunt as a source. This does little to enhance confidence in Hunt's findings; it would be more significant if an independent scholar found the same results as Hunt did.

After students have spent time reading and summarizing one or more articles (depending on the length of the article), the final task is to synthesize their findings with fellow group members. Each student shares what they found in their article(s) with their teammates, and then the group tries to reach some level of agreement on what they believe really happened on Rapa Nui. The culmination of this process is a co-authored paragraph that each group submits by the end of the class period, stating the group's conclusions. ${ }^{24}$ While student responses varied, the most common interpretation was to try to reconcile the arguments of Diamond and Hunt in some way. For example, students often concluded that Hunt was right to emphasize significance of the rats in the island's

24 All of the written work described here - the research questions, the citation information, the justification for the reliability of the source, the article summaries, and the synthesis - are written by each group in a shared Google Doc that was ultimately shared with me. 
deforestation, while still holding that archaeological findings support Diamond's general narrative of resource depletion and increased violent conflict on the island. Another common "conclusion" in these syntheses was continued uncertainty. This, in itself, provides a frustrating but valuable lesson about the historical endeavor-that interpretive disagreements are not necessarily easily resolved by a brief foray into research.

\section{Assessment of Long-Term Effectiveness: Student Recollections, 20 Months Later}

As a means of assessing the impact of these lessons, I conducted surveys in August 2018, asking students for their insights regarding how to grapple with competing historical interpretations of the same event or subject. I surveyed 58 current juniors, who had completed the Rapa Nui unit discussed in this article during their Freshman World History class. Necessity required that I had to survey these students long after the fact-I recently switched from teaching World History to US History and therefore no longer have cause to teach about Rapa Nui-but these circumstances did allow me to try to assess the long-term impact of the unit. Presumably, if students could still articulate the significance of these lessons after 20 months, that would suggest especially powerful evidence of the utility of these lessons.

In the survey, I briefly reminded students about the perspectives of Diamond and Hunt, ${ }^{25}$ and then posed the open-ended question: "Based on your (perhaps fuzzy) recollections of those Easter Island lessons, what were some of the 'big points' that I was trying to make about history during that unit?" After combing through the 58 student responses, it was possible to discern certain themes

\footnotetext{
25 The introductory text was, "Remember the lessons we did about Easter Island, where you read the articles by the two different historians? One of them, Jared Diamond, argued that the Rapanui chopped down all their trees and destroyed their own environment. The other guy, Terry Hunt, said that Jared Diamond was wrong. He argued that rats were more responsible for the decimation of the forest, and there was no big human-induced social collapse."
} 
in the responses, which happily coincided with many of the key insights that I hoped the Rapa Nui unit would instill in students. Here are descriptions of those themes, along with the titles I gave them:

- Multiple Causation: Many students made a distinct point, that often there are multiple historical factors that lead to a historical outcome. In other words, one reason that there are multiple interpretations is that there is more than one "right answer."

- Different Scholarly Interpretations: Many students made the (perhaps obvious but nevertheless important) point that historians often disagree and can draw different conclusions about the same historical topic.

- Bias Guides Interpretation: Many students argued that the case of Easter Island shows that a historian's bias or agenda can shape their historical argument, or perhaps compromise its reliability (sometimes, students specifically identified Diamond's environmentalist agenda).

- Lack of Evidence: Many students wrote that a lack of sources makes it challenging for the historian to interpret what happened on Easter Island.

- Difficult to Determine Truth: Many students emphasized that it was hard, or perhaps even impossible, to know what really happened in the past (not surprisingly, many of these students also discussed the "lack of evidence" issue mentioned above).

Since I was interested in the frequency with which students mentioned certain ideas, I coded each response based on whether it mentioned any of the above themes (most responses mentioned multiple themes). Because this involved some subjective decision making, I enlisted the help of two students as research assistants, who also independently coded each response based on themes I identified. We ultimately reconciled any disparities, and I recorded 
that data in Table 1, which lists the title and description of each of the themes, the numerical and percentage frequency of each theme, and one or two example student responses that illustrate each response category.

\section{Table 1}

\begin{tabular}{|c|c|c|c|}
\hline \multirow{2}{*}{$\begin{array}{l}\text { Response Category } \\
\text { Title }\end{array}$} & \multirow{2}{*}{ Response Category } & \multicolumn{2}{|c|}{ Frequency } \\
\hline & & Number & Percentage \\
\hline Multiple Causation & $\begin{array}{l}\text { Multiple different factors collectively } \\
\text { cause a given historical event/process; } \\
\text { both explanations could have merit }\end{array}$ & 20 & $34.5 \%$ \\
\hline \multicolumn{4}{|c|}{$\begin{array}{l}\text { Example Response: "Many things affect history. There were many reasons why the environ- } \\
\text { ment collapsed - likely both arguments are warranted because both rats and people were } \\
\text { factors." }\end{array}$} \\
\hline $\begin{array}{l}\text { Different Scholarly } \\
\text { Interpretations }\end{array}$ & $\begin{array}{l}\text { Historians often disagree/can arrive at } \\
\text { different conclusions about the same topic }\end{array}$ & 37 & $63.8 \%$ \\
\hline \multicolumn{4}{|c|}{$\begin{array}{l}\text { Example Response: "History leaves many things open to multiple explanations and inter- } \\
\text { pretations - a lack of complete documentation makes many topics partially speculative. } \\
\text { However, logic and reasoning is a huge part of history: Examining the relationships between } \\
\text { multiple events and linking many pieces of evidence is essential for making assumptions that } \\
\text { are probable." }\end{array}$} \\
\hline $\begin{array}{l}\text { Bias Guides } \\
\text { Interpretation }\end{array}$ & $\begin{array}{l}\text { One/both of the historical arguments were } \\
\text { affected by bias/agenda of the authors }\end{array}$ & 19 & $32.8 \%$ \\
\hline \multirow{2}{*}{\multicolumn{4}{|c|}{$\begin{array}{l}\text { Example Response: "What is the bias of the person writing the article? Jared Diamond's goal } \\
\text { was/may have been to promote awareness for the environment, and so he may have over } \\
\text { exaggerated details or interpreted them in specific ways to make his point." } \\
\text { Example Response: "History is not always an unbiased explanation. Bias is completely } \\
\text { unavoidable, and sometimes intentional. Therefore, trusting every source you meet is not the } \\
\text { way to go about research. Each source should be approached with an equal amount of doubt } \\
\text { and further research can always be done, and most often should be done. Multiple sources } \\
\text { are necessary for a rounded view of the topic." }\end{array}$}} \\
\hline & & & \\
\hline Lack of Evidence & $\begin{array}{l}\text { Sometimes there is insufficient evidence } \\
\text { (making it hard to draw conclusions) }\end{array}$ & 16 & $27.6 \%$ \\
\hline \multicolumn{4}{|c|}{$\begin{array}{l}\text { Example Response: "I remember you compared history to a dark room with only a small } \\
\text { hint of light, and historians were trying to determine as much as they could of what was in } \\
\text { that room. Due to this lack of light, inferences can be varied and in many cases, we can't } \\
\text { really know everything, but we can do our best to understand." }\end{array}$} \\
\hline $\begin{array}{l}\text { Difficult to } \\
\text { determine truth }\end{array}$ & $\begin{array}{l}\text { It may not be possible to know what really } \\
\text { happened in the past }\end{array}$ & 14 & $24.1 \%$ \\
\hline \multicolumn{4}{|c|}{$\begin{array}{l}\text { Example: "There are multiple possibilities. History is a very muddled subject. We know } \\
\text { very little for sure. We have a small bundle of facts which we have to use to piece together a } \\
\text { plausible explanation. People don't know everything, and people are very often wrong about } \\
\text { history." }\end{array}$} \\
\hline
\end{tabular}


It is hard to know whether these results represent a "success"theoretically, an ideal result would be that $100 \%$ of students mentioned all five of these themes (or perhaps others). However, it is unrealistic to assume that every student taking an in-class survey would be able (and willing) to spontaneously produce every possible implication of lessons delivered 20 months prior. While I am unsure what percentage thresholds would represent "success," I can at least make the more tentative statement that it is heartening that a significant number of students mentioned each of these themes (and 56 of 58 students mentioned at least one of them), and that several students offered particularly sophisticated insights that demonstrated complex historical thinking and a strong recollection of the lessons.

In addition to the specific question about Rapa Nui, I also posed three more general survey questions, asking students about the challenge of considering two competing historical interpretations. The survey started with a statement that read: "Imagine you read two articles about the same historical topic. Both are written by historians with $\mathrm{PhDs}$, but they have significantly different interpretations of the subject." This introductory text was followed by three open-ended survey questions. For example, one asked: "What criteria should you —as a student doing research—consider when trying to determine the most convincing explanation of that historical topic? ${ }^{26}$ After collecting the student responses, I identified common themes and then coded the qualitative data with the help of research assistants-the same basic procedure that I followed with the Rapa Nui question. ${ }^{27}$ Additionally, I asked the same survey questions to a control group: students at my school who had never taken my class. This allowed me to assess whether students who had taken my class were disproportionately

26 The other two questions were: "Q1: What factors might lead historians to draw different conclusions about the same historical subject?" and "Q3: After reading and considering the two articles, what additional steps could you take that would help you determine the most persuasive explanation of that historical topic?

27 I would like to thank my research assistants: Raine Bernhard, Solomia Dzhaman, Annette Lee, Samuel Li, Kate Snyder, Bella Solis, Jessica Valete, and Tina Wayne. 
likely to discuss certain themes in their responses. If my students were more likely to mention a certain theme than were students in the control group, one could perhaps tentatively conclude that the Easter Island lessons had influenced my students' historical thinking.

I entered into this process well aware of the shortcomings of such an approach. First, there was no way of knowing that any significant differences that presented themselves actually arose as a result of the Easter Island lessons, rather than many other lessons and projects that dealt with historiographical thinking. Secondly, the control group (which was mostly freshmen, as I have taught all the juniors and seniors at my school) was younger than my treatment group, and therefore perhaps a difference in intellectual maturity would be responsible for any differences rather than any lessons that I had taught. Third, the subjective nature of the coding process (even though I tried to control for this by using multiple research assistants) endangers the reliability of any data. Finally, this kind of survey is not the best instrument to assess acquisition of historical thinking skills. Despite these shortcomings, I will share some of my findings, while acknowledging that they should be taken with caution.

After analyzing the data, I found that for almost all of the "response categories," there was no significant difference between the response frequencies of my students and those of the control group. ${ }^{28}$ For example, as you can see in Table 2, my students were just as likely to posit that evidentiary issues could be responsible for differences between competing historical interpretations.

28 There was only one other response category with a statistically significant $(p<.05)$ difference between the treatment and control groups. When asked, "What factors might lead historians to draw different conclusions about the same historical subject?" my students were significantly more likely to speculate that the two historians were focusing on two different aspects of the same topic. As one student put it, "They may also be choosing to focus on different parts of a historical subject, such as emphasizing environmental factors more than cultural ones, and hence draw different conclusions." Still, this wasn't a frequent response (15.5\% of my students mentioned this issue, compared to just $4.7 \%$ of the control group, for $p$-value of .045). 
However, there was one important response category for which the difference between the treatment and control group was statistically significant $(\mathrm{p}<.05)$ : My students were significantly more likely to say that the bias or agenda of the historian could be responsible for differences between historical interpretations. Forty-four point eight percent of my students mentioned bias as a relevant criterion, while just $25.0 \%$ of students in the control group did the same $(\mathrm{p}=.021)$. This was obviously an intriguing finding, since the Rapa Nui lessons discussed in this article focus heavily on the issue of potential bias (and importantly, my students responded to this particular survey question before being reminded of the Rapa Nui unit). However, if this difference is related to my teaching at all-and I am not convinced that it is-I would argue that it is the result of my general focus on bias and agenda shaping historical interpretations (which shows up throughout my curriculum), rather than the Rapa Nui unit specifically. Indeed, I would generally argue that learning to think historically is an ongoing process rather than a matter of flipping an "on/off" switch. Historical thinking skills are gradually honed over a long period of time rather than quickly achieved as a result of a discrete lesson.

\section{Table 2}

\begin{tabular}{|c|l|c|c|c|}
\hline \multicolumn{6}{|c|}{$\begin{array}{c}\text { Question 2: What criteria should you-as a student doing research-consider when } \\
\text { trying to determine the most convincing explanation of that historical topic? }\end{array}$} \\
\hline $\begin{array}{c}\text { Response } \\
\text { Category } \\
\text { Title }\end{array}$ & Response Category & $\begin{array}{c}\text { Treatment } \\
\text { Group } \\
\text { Frequency }\end{array}$ & $\begin{array}{c}\text { Control } \\
\text { Group } \\
\text { Frequency }\end{array}$ & p-value* \\
\hline $\begin{array}{c}\text { Author's } \\
\text { Credibility }\end{array}$ & $\begin{array}{l}\text { Determine the credibility of the historian } \\
\text { (e.g. based on scholarly credentials) }\end{array}$ & $31.0 \%$ & $37.5 \%$ & .453 \\
\hline Bias & Consider the historian's bias or agenda & $\mathbf{4 4 . 8 \%}$ & $\mathbf{2 5 . 0 \%}$ & $\mathbf{. 0 2 1 * *}$ \\
\hline Evidence & $\begin{array}{l}\text { Determine if author uses sufficient evi- } \\
\text { dence, or assess reliability of evidence }\end{array}$ & $48.3 \%$ & $50.0 \%$ & .849 \\
\hline $\begin{array}{c}\text { Logical In- } \\
\text { terpretation }\end{array}$ & $\begin{array}{l}\text { Determine whether the author's interpre- } \\
\text { tation of the evidence is logical }\end{array}$ & $20.7 \%$ & $14.1 \%$ & .333 \\
\hline $\begin{array}{c}\text { Context of } \\
\text { Publication }\end{array}$ & $\begin{array}{l}\text { Consider when the scholarship was } \\
\text { written, or why it was written }\end{array}$ & $24.1 \%$ & $18.8 \%$ & .468 \\
\hline
\end{tabular}

*Two-tailed p-value based on a Z-Test that was used to compare the two proportions.

**Statisitically significant, $\mathrm{p}<.05$ 


\section{Conclusion: Promoting a Healthy Level of Skepticism about Historical Interpretations}

Hopefully, readers find my description of this lesson on Rapa Nui useful. Perhaps some might choose to teach a similar lesson using the same articles by Jared Diamond and Terry Hunt-I would certainly recommend doing so, as it led to particularly spirited discussion in my classroom. However, at a deeper level, I offer this description of classroom practice as just one example of how to expose students to historiographical debate as an integral element of history class. If history education scholar Bruce VanSledright is correct that in a traditional history class, "the obsession appears to be with the products of historical study, not with the practice of doing it," then focusing on historiographical debates seems like a valuable antidote. ${ }^{29}$ In a World History class, for example, one could cultivate historiographical thinking by exploring different explanations of the fall of the Roman Empire (or an even more delectable historiographical debate, is "decline and fall" even the right paradigm for thinking about the Roman Empire during Late Antiquity?). In a U.S. History class, the possibilities also abound: Was the American Revolution radical or conservative? Why did slavery replace indentured servitude in the American South? Did the experience of settling the frontier create a distinctive American identity, as famously argued by Frederick Jackson Turner? ${ }^{30}$ To grapple with these historical questions, students would need to critically unpack the work of scholars-carefully identifying the evidence they use, the interpretative claims supported by that evidence, and the conclusions those scholars draw. And students would undoubtedly need to assess whether historians have an agenda that might shape their argument. These students

29 Bruce VanSledright, “Confronting History's Interpretive Paradox While Teaching Fifth Graders to Investigate the Past," American Educational Research Journal 39, no. 4 (Winter 2002): 1091.

30 For ideas about how to incorporate historiographical debate into a U.S. History curriculum, a commonly used text is Larry Madaras and James SoRelle, eds., Taking Sides: Clashing Views in United States History, 17 $7^{\text {th }}$ ed, (New York: McGraw-Hill, 2017). There are two volumes that collectively cover the scope of U.S. History. 
would experience history class as a forum for interpretation and argument rather than a site for the accumulation and regurgitation of historical data. In other words, such lessons would help students hone historiographical thinking.

While I hope I have successfully argued that promoting this kind of thinking is a good thing for students, there is also a line of thinking that should be discouraged. Consider the following set of logical conclusions that a (clever) student might make: If history is not a collection of facts but instead an array of competing interpretations, then there is no "true past" that we can recover. Taken to the extreme, the student might conclude that all interpretations are flawed and none should be considered any more valid than any other interpretation. Instead, all historical arguments are merely products of an author's agenda that should only be considered as expressions of the bias of the author (or the teacher!). Or alternatively, even if some interpretations are truly more or less valid, we cannot reliably deduce which are better than others, since our own (confirmation) biases cloud our judgement. Thus, the healthy skepticism of the critical thinker can descend into epistemological nihilism.

It need not. While this kind of lesson hopefully forces students to destabilize the authority of scholars and grapple with the potentially problematic impact of an author's agenda, it also is premised on the idea that a consumer of knowledge should be striving to determine the best available interpretation. Students should discard some theories after the bare minimum of investigation; after all, some authors offer wild speculation about the moai being built and transported by extraterrestrial visitors. ${ }^{31}$ For more empirically grounded arguments, students should be

\footnotetext{
31 For a classic work of conspiratorial pseudoscience, see Erich von Daniken, Gods from Outer Space: Return to the Stars or Evidence for the Impossible (Toronto: Bantam Books, 1968). His ideas were popularized for a new generation by The History Channel's Ancient Aliens, which discussed extraterrestrial explanations regarding the moai in the series pilot and in several subsequent episodes. Needless to say, numerous websites link Easter Island to alien visitors.
} 
able to map the anatomies of competing arguments and identify key points of disagreement between competing interpretations. Then they can conduct follow-up research that seeks to resolve those disputes. Thus, students can arrive at their own tentative conclusions about "the truth" - or at least, come to decide which interpretation or combination of interpretations seems most probable based on the existing evidence. Such an endeavor is vital to historical and historiographical thinking, as well as informed citizenship and the intelligent consumption of news on the internet. While this lesson on Rapa Nui is surely insufficient for students to master these skills, it provides an incremental means to hone them, giving them practice asking questions like: What evidence is the author using? Are the interpretations persuasive? Can I do further research to corroborate or challenge this interpretation? At the very least, I hope the lesson illuminates the fact that these are questions that should be asked rather than blindly trusting what a historian or history teacher says-or whatever comes up first in the Google search or atop the social media feed. 